\title{
The signifier in motion: the movement of language in Psychoanalysis and in Aristotle's linguistic theory
}

\author{
Shirley Sharon-Zisser ${ }^{\star}$ \\ Department of English at Tel Aviv University / New Lacanian School (NLS) \\ and World Association of Psychoanalysis (AMP)
}

\begin{abstract}
The article examines the relation between language and movement in Freud's Project for a Scientific Psychology and Lacan's seminars four and seven, in the first of which Lacan aligns the anguishing movement in which the subject knows he is caught up with Aristotle's theorization of infinite movement in Aristotle's Physics. The article argues that it is also treatment of the category of scheme $(\sigma \chi \tilde{\eta} \mu \alpha)$ - at once elocutionary form and corporeal motion - that psychoanalysis can glean significant knowledge concerning the relation of language and movement, especially stylized movement that is of the order of the discontinuity of the symbolic, but which nevertheless intricates the flesh that enjoys.
\end{abstract}

Keywords: Freud; Lacan; Aristotle; scheme; movement.

Language moves. Its rhetorical usage, Cicero proclaims, aims to create "impetus" and "perturbation," (impetu et perturbatione) (CICERO, 1948, 2.42:179), e(a)ffects whose implication in the category of motion is indicated not only by their derivation from what rushes and turns, ${ }^{1}$ but by the very denomination of the aim itself: "movere" (CICERO, 1948, 2.51:235). What had been an aim for the ancient rhetorician remains so for the contemporary psychoanalyst, of whom the rhetorician, Lacan (1993, p. 219) writes, is the predecessor, no less preoccupied with the question of the subject's relation to the signifier.

In the terms of Lacanian psychoanalysis, affect such as can arise from rhetorical argumentation or analytic intervention is a signal of an operation Jacques-Alain Miller (2000) has called "corporisation": the transformation of a unit of language into a body event. Hence Lacan's comment at the beginning of the seminar on Anxiety (2014, p. 14) that it is not incidental that it is in a work on language, the Rhetoric, that Aristotle discusses affect. The Rhetoric's structure - a "net" of linguistic references in which affect is caught up - resonate the structural place of affect as quantum moored in the net of unconscious signifiers (LACAN, 2014, p. 14). That language moves is thus a consequence of the relation between affect and the signifier such as founding Freudian metapsychology and the praxis it enchains.

This praxis merits the name, Lacan (2014, p. 15) continues, of an "erotology", a term anagrammatically indexing the rhetoricity in which this praxis is anchored. In a later seminar, Lacan qualifies analytic praxis as that of a rhetorician. This is not only because analytic praxis involves an operation on the real by means of the symbolic, on what is impossible in a subject's life by means of language. The praxis of analysis qua erotology is rhetorical primarily because the act on which it is predicated is a "rectification" of the subject with the impasses of which

\footnotetext{
^Address for correspondence: Department of English - Tel Aviv University. Ramat Aviv 69 978. Israel. E-mail: shirleyzisser@gmail.com

${ }^{1}$ Impetu is a derivative of petere (to rush); perturbatione is a derivative of turba or turbo (turmoil), whose etymological root is the Sanskrit turāmi, to hasten. See Charlton T. Lewis and Charles Short, A Latin Dictionary (Oxford, 1956).
}

he complains; real points of a psychic reality (LACAN, 1977-1978, p. 2). Rectification within the practice of an erotology seeking to move (effect a subjective transformation) precisely at an excruciating point in subjective life - "cutting edge" point of anxiety (LACAN, 2014, p. 15) - such is the ethical orientation, confirmed by anagram and equivoque through which an unconscious knowledge speaks, of psychoanalysis qua rhetorical, a practice utilizing language to transitively move.

But is it possible to think language also as what moves intransitively? Is language conceivable, that is, not only as a static synchronic system in whose throes the enjoying substance of the speaking being is caught up but as enjoying substance altering configurations? The work of Freud and Lacan certainly suggests as much. So, albeit differently, do Aristotle's works on language - the Rhetoric, the Poetics, and the Sophistical Refutations - in their unfolding of the rhetorical category of scheme, a signifier whose polyvalence, in Aristotle and beyond, gives pause to an analytic ear. In what follows, I consider Freud and Lacan's treatments of various intersections of language and movement, articulating these treatments with a psychoanalytic reading of the category of scheme in Aristotle's works on language. The result, I propose, may teach us something more about the relation between pulsating organic matter upon the qualitative and quantitative changes it undergoes and the rhetorical, the theory of language whose forms, Lacan (2007a, p. 221) suggests, are also the forms of modulation of unconscious signifiers.

In Freud's metapsychological work from its inception in the Project for a Scientific Psychology of 1895, language moves. For the components of the psychic apparatus Freud postulates there in order to account for the clinical phenomena of the neuroses, components dubbed "Vorstellungen" (representations), and hence signalled as partaking of the order of semiosis, are, Freud writes, derivatives of a "quantity in a state of flow [fließender]" which is "subject to the general laws of motion (Bewe- 
gungsgeset)." ${ }^{2}$ This quantity passes through the organic matter of the nervous system, characterized by the "irritability [Reizbarkeit] of protoplasm" of which it is the inheritor (FREUD, 2001, v. 1, p. 296; 1999, Bd. 18, S. 389). Where this matter is not only irritable but also resistant, a quality Freud attributes to a category of neurons he names " $\psi$," its irritation by the quantity that passes through it alters it (verändert), leaves behind a trace that is the constituent of what Freud (2001, v. 1, p. 299-300; 1999, Bd. 18, S. 391) defines as memory. The memory trace that Freud $(2001$, v. 1 , p. $365 ; 1999$, Bd. 18, S. 456) would later specify as unconscious, then, is nothing but the "representation [Darstellung] of all the influences which $\psi$ has experienced from the external world", that is to say, the product of the alteration of irritable organic matter by what flows through it, made possible by the matter's resistance. It is an instance of writing whose resisting substrate is protoplasmic, made of flesh.

In the 1915 essay on "The Unconscious" Freud specifies the nature of what writes in this substrate. First defined as a "flow" subject to "the laws of motion," what leaves a trace behind in the psychic apparatus is now precised as a particular motion, the "Triebregung" or motion of the drive. ${ }^{3}$ What is written in the unconscious stems from motion and hence points to it. It is because of the ostentive function of the unconscious trace that Freud (1999, v. 10, p. 276) renames it, specifying it as neither Darstellung nor Vorstellung but Vorstellungsrepräsentanz what is of the order not of representation but of representativeness.

As representative of representation, the Vorstellungsrepräsentanz is at once symbolic and indexical. It is, Lacan (1958-1959, p. 8) emphasizes, "strictly equivalent to the notion and to the term of signifier", a unit of language subject to the conventions of a combinatory. At the same time, the Vorstellungsrepräsentanz is "an isolated fragment" of an order "neither conscious nor unconscious," which has "an incidence from its own action" (LACAN, 1958-1959, p. 7). This action is nothing but the circuiting of the drive from one point of an erogenous zone to another, a reality radically other to components of language, that is to say, in Lacan's terms, real. The components of the symbolic, order of language, that is, are, if unconscious, fragments of a real whose reality is that of constant motion of which they are also the product. Unconscious signifiers move. They do not cease to manifest the pulsating irritation of resistant organic tissue of which they are the precipitate, even as they sublate it, perform what Freud adequately names a "Reizaufhebung" (FREUD, 1999, Bd. 18, S. 411). ${ }^{4}$

\footnotetext{
2 "Project for a Scientific Psychology" (FREUD, 2001, v. 1, p. 296). Quotations in German are from the Gesammelte Werke, ed. Anna Freud, 18 vols. [18 Bäden], Frankfurt, 1999. (FREUD, 1999, Bd. 18, S. 387).

3 "Das Unbewusste" (FREUD, 1999, Bd. 10, S. 276). Strachey's translation of "Triebregung," literally "motion of the drive," as "instinctual impulse" (FREUD, v. 14, p. 177) somewhat obscures the kinetic inflection of Freud's term.

${ }^{4}$ Strachey's translation "removal of stimulus" (FREUD, 2001, v. 14, p. 317) misses the implication implicit in Freud's resorting to the term "aufhebung" upon its Hegelian connotations - that not all irritation occasioned by the Not des Lebens is ever removed by specific action.
}

And yet this movement is precisely what seems alien to the psychic apparatus as Freud discovers it. The processes (conversions, substitutions, over-excitations) logically deduced from neurotic phenomena which are these apparatus's indices can only be explained, Freud (2001, v. 1, p. 295-296) writes, by its being governed by "the principle of inertia": the tendency of components to "divest themselves" (entledigen, literally free themselves [2001, v. 1, p. 296; 1999, Bd. 18, S. 388]) of protoplasmic irritation, be its origin in the "external world," understood in terms of physics as "powerful masses which are in violent motion [heftig bewegten Massen]" and which transmit their motion [Bewegung fortpflanzen]" (2001, v. 1, p. $305 ; 1999$, Bd. 18 , S. 397$)^{5}$ or in what Freud (1999, Bd. 18, S. 390) calls the "Not des Lebens" ("need of life"). Neurotic phenomena, more often than not manifest in movement or its disturbance - the hysteric's facial tics, convulsions, or astasia-abasia, the obsessional's incessant motions in space to the benefit of a seemingly superfluous action of which the Ratman's series of stunted train journeys are a signal example, ${ }^{6}$ the force stronger than the phobic's conscious volition that propels him away from an object or site saturated with enjoyment - all these are but products (and hence indices) of the tendency towards the undoing of the motion of irritated protoplasm Freud (1999, Bd. 18, S. 390 et seq.; 2001 , v. 1, p. 297 et seq.) finds at the logical foundation of unconscious representation, a tendency whose mode of implementation he names "Abfuhr" (discharge).

Nor is the motile profile of neurotic symptoms $A b$ fuhr's only outcome in the sphere of motion. Implicating muscular tissue, the aberrant and aborted motion typifying neurotic symptomatology seems but a variation on the "motor excitation" carried out by the "apparatus of motility" on behalf of the "trend to discharge" (Abfuhrtendenz) (FREUD, 2001, v. 1, p. 318; 1999, Bd. 18, S. 406). So is the "specific action" (spezifische Aktion), the "alteration in the external world" (Veränderung in der Außenwelt) carried out to appease the Not des Lebens (FREUD, 2001, v. 1, p. 318; 1999, Bd. 18, S. 410), "not distinguishable," Lacan (1999, p. 41) says, "from what takes place when a motor reaction occurs". The initial "exteriority" (fremde) (2001, v. 1, p. 318; 1999, Bd. 18, S. 410) of what carries out specific action, Lacan (1999, p. 71) teaches, the movement of limbs to the benefit of the propagation of life, is but a manifestation of extimacy, of what is "strange to me, although it is at the heart of me". Movement is strange to the being affected by the signifier whose intricacies Freud begins to unfold in the Project. Manifest at the foundation of the unconscious signifier as protoplasmic irritation, movement emerges in the musculature in various forms, all seeking movement's own extinction.

\footnotetext{
${ }^{5}$ The German "fortpflanzen" has the sense not only of 'moving elsewhere' but also of 'propagating.' The masses Freud speaks of hence both move and in doing so perpetuate their motion.

${ }^{6}$ See Freud (2001, v. 10, p. 170-191), "Notes upon a Case of Obsessional Neurosis".
}

Fractal, Rev. Psicol., v. 28 - n. 3, p. 307-315, 2016 
But there are various intensities to movement as what protoplasmic irritation conditions so as to consume, that of the muscular or motor apparatus by no means the highest of them. That Freud (1999, Bd. 18, S. 389) should, in the opening paragraphs of the Project, refer to this apparatus as a "Muskelmachine" (muscle machine $)^{7}$ points to what will be the text's very last pronouncement: the qualification of the motions of this apparatus as mechanical, "monotonous" (2001, v. 1, p. 389; 1999, Bd. 18, S. 477). ${ }^{8}$ That this should be so has to do with a qualitative difference nevertheless distinguishing pure motor action from the motions supporting specific action and the motor phenomena of the neuroses, only seemingly its derivatives. For while neurotic symptoms involving motion are the products and indices of unconscious representations, kinetic monuments to memory traces inscribed in resistant organic matter (the $\psi$ neurons) to which too much unpleasure is attached, and while specific action, Freud (1999, Bd. 18, S. 411; 2001, v. 1, p. 318) says, gives rise in $\psi$ to a "Bewegungsbild" unconscious representation of a motion that brought about an experience of satisfaction (Befriedigungserlebnis) (2001, v. 1, p. $317 ; 1999$, Bd. 18, S. 410), other motions of the musculature, Freud says towards the end of the Project, "are not associated with word-presentations" (Wortvorstellungen) (2001, v. 1, p. 387; 1999, Bd. 18, S. 477). They are a manifestation of discharge that is indifferent to language because what triggers it is a change in a substrate that does not resist that Freud (2001, v. 1, p. 314) names the " $\phi$ neurones." Permeable to the flow of quantity through them, $\phi$ neurones are affected by it in a way related to but not identical with irritation. Their quasi-stimulation, moreover, "does not persist for long and disappears towards the motor side," leaving not a trace behind (FREUD, 2001 , v. 1, p. 314) as the substrate's lack of resistance does not allow it to become a writing. It is the relation of the motion involved in neurotic symptoms and in specific action to writing, unconscious inscription resulting from the irritation of a protoplasmic substrate that resists, then, that accounts for the relatively higher intensity of these symptoms with respect to motor discharge that is without reference to representation. Such motor discharge, Lacan (1999, p. 42) says, has a "diminished character".

What is the nature of this relation between writing and motion? In the case of the motor phenomena of the neuroses, the panoply of motion aborted or in disarray paraded daily in the analytic clinic, what is at stake is the relation Freud names "repression": the substitution of such symptomatic motion for an inscription whose translation into conscious thought would entail too unbearable a unpleasure. As for specific action, the relation between unconscious inscription and movement has to do with the inherent difference between the action's inaugural and subsequent instances. For once an inaugural specific action treats the emergency of the human subject's native Hilflosigkeit (helplessness) (FREUD, 1999, Bd. 18, S. 411; 2001, v. 1, p. 318), giving rise to an experience

\footnotetext{
'Strachey translates the term as "muscular mechanisms" (FREUD, 2001, v. 1 , p. 296)

${ }^{8}$ See also Lacan's comment on this passage (1999, p. 41).
}

of satisfaction memorialized as an unconscious inscription of movement, an inherent gap, Lacan (1999, p. 41) points out, opens up in human experience. An unbridgeable distance emerges between the inaugural inscription of movement that stopped upon a satisfaction and the memory traces left behind by any attempt to repeat this movement. This distance is cause of discontent, as are the symptomatic motions precipitated by repression. But it is precisely this discontent that generates another kind of movement implicating language: the "centripetal" movement "toward speech" (LACAN, 1999, p. 41).

Were it not for the discontent, intense to the point of pain, born of motor symptoms or of the constitutive distance between desire and satisfaction, the conscious subject would know nothing, Lacan (1999, p. 32) writes in his rereading of Freud's Project, "of the movements that belong to the unconscious". In Freudian terms, these are nothing but the movement of units of irritated organic matter re-presenting motion excluded from representation and of their collisions, coalitions and conjoinings. Only a "dim perception" of the specifics of this movement would be possible, Lacan (1999, p. 32; 49) says, limited at the most to "opposing [moments of] mobility and immobility" were it not for "something in the sensory-motor circuit" - the experience of pain - that "manages to interest the $\psi$ system at a certain level". Between a motor phenomenon that is unpleasant or falls short of satisfaction and what it manages to interest - the irritated protoplasm that is the unconscious inscription - between movement and movement, an effort is generated whose product, "perceived retroactively," is a conscious "Wortvorstellung" (LACAN, 1999, p. 49).

Though this effort implicates the organic matter at the foundation of the signifier, its locus cannot, Lacan (1999, p. 51) points out, be "easily identified with a neuronic apparatus," for Freud locates it "between glove and hand, so to speak" - between words that are conscious and the perceptions (Wahrnehmung) that, if encountering neuronal matter that resists, can generate unconscious inscriptions (FREUD, 2001, v. 1, p. 387; 1999, Bd. 18, S. 477). The centripetal effort thanks to which the unconscious can unfold inside out and be encountered, then, takes place not only between two instances of movement but at the same time between two instances of language: the unconscious signifier and the conscious word presentation.

Extended between two instances intricating language and motion, the unfolding of the topology of the subject Freud details in the Project displays the same intrication. This unfolding is nothing but, Lacan (1999, p. 49) explains, "the articulated movements of words" - whose manifestation is at least double. In terms of Freud's Project, words transitively move not only because, as unconscious signifiers, their substrate is irritated protoplasm whose units collide and coalesce, but also because the further stimulation of this substrate by intense unpleasures at the level of the motor apparatus instigates a centripetal procession within the unconscious "from Vorstellung to Vorstellung, from representation to representation" (LACAN, 1999, p. 49). The outcome of this procession, ad- 
vancing in "tiny steps" no less monotonous than those of the motor apparatus instigating them (LACAN, 1999, p. 49 ) is not only conscious word presentations seizing something of the unconscious, but the articulation of these word presentations in the plastic medium of speech.

Linking unconscious signifiers (inscribed $\psi$ neurones) with sound presentations (Klangvorstellungen), the process of "speech association" (Sprachbildern) (FREUD, 2001 , v. 1, p. 364 ; 1999, Bd. 18, S. 455) which is the end of the unconscious' folding inside-out Lacan (1964/1978, p. 156) would later denominate its syncopating pulsation lends these unconscious signifiers which might have otherwise remained obscure "presence [and] structure" (LACAN, 1999, p. 32). Primarily, "one's own scream serves to characterize the object" inscribed in the unconscious as hostile (FREUD, 2001, v. 1, p. 366, italics in the original). The subject's scream becomes the hostile object's only palpable form, which is not static (LACAN, 1999, p. 32). Produced by motions of the buccal orifice, the scream as Freud's prototype for speech is an instance, Lacan (1999, p. 48) says, emphasizing the "strangeness" of this Freudian notion, of the "Bewegung, movement of speech". For the speech in which the subject screams defamiliarizes the relative monotony, at once of motor action and of the weary motion of unconscious signifiers towards it, synecdochizing the intensity of irritated protoplasm, of the unpleasant memory traces it both shapes and recognizes.

In Freud's Project as Lacan (1999) rereads it in The Ethics of Psychoanalysis, then, representation is intricated with flesh in motion from its logical outset as Niederschrift, primal unconscious writing (FREUD, 1962, p. $151 ; 2001$, v. 1, p. 234), but it is when representation becomes speech that it reaches the peak of its intensity for the subject. This is not only, however, because the acoustic medium gives unconscious representation palpable form, but also because it does so at the very moment unconscious representation reaches the term of its percolation towards consciousness and becomes an instance of what Lacan (1998a, p. 348) calls "se savoir exister" (knowing one exists). Knowing one exists, a consequence of being affected by language, Lacan (1998a, p. 348) says in his rereading of Freud's case of Little Hans, gives movement a "special value". For the minimum of detachment from life involved in knowing one exists means, Lacan (1998a, p. 348) says, one may be "seized by a movement without being totally implicated in it," or become a movement's remainder, a fallen object it leaves behind. The emergence of speech is simultaneous with language's rising to a second power, seizing itself in an apperception of itself - and since, as Freud indicates in the Project, language at once indexes, manifests and gives rise to motion - of itself as movement.

The movement at stake, however, is not "uniform movement" (LACAN, 1998a, p. 348) not the movement of muscular machinery indifferent to language nor of what Freud (2001, v. 1, p. 233) calls the rewriting, "several times over" of unconscious traces making their way to conscious word presentations, monotonous movements, Lacan (1998a, p. 348) says, in which “one does not sense one's self" and in which, therefore, "one is saved". The movement whose measure may be taken from the moment language rises to the second power and becomes conscious speech is different from the monotonous movements of which the subject remains in blessed ignorance. It is the opposite, Lacan (1998a, p. 348) says, of what Aristotle defines as "linear movement" - the constant rotational movement Aristotle defines as fundamental, the condition for the perception of any finite locomotion from "a point from which that which is in motion can be said to start and a point at which it can be said to finish its course". 9

This movement is not without subjective perils. Unlike in rectilinear motion, Aristotle writes, "in circular motion there are no ... definite points: for why should any one point on the line be a limit rather than any other?" (ARISTOTLE, 1984, 8.9.265) Rotational motion as fundamental is "the only motion whose course is naturally such that it has no starting-point or finishing-point in itself" (ARISTOTLE, 1984, 8.9.265). Rotational motion is infinite, an attribute Lacan (1998b, p. 103) in his later teaching would associate with an Other jouissance which escapes the moderating, separating effects of the symbolic and situated as real. Rotational motion as Aristotle theorizes it has "the continuity of the real," Lacan (1998a, p. 348) says even much earlier, undisturbed by the "discontinuities of the symbolic.". In more modern terms, Lacan (1998a, p. 348) says, the infinite continuity of what Aristotle describes as rotational motion is nothing but "acceleration", the growing velocity of a thing in motion which the force of inertia resulting from its own mass is not sufficient to hinder. Knowing one exists means "sensing [this] inertia correlative to acceleration" without being able to bring acceleration to an end. It is an encounter with a real without limit, an encounter whose affective corollary is anxiety such as seizes Freud's Little Hans (1998a, p. 348). Nothing causes Hans greater anxiety (größere Angst), Hans's father reports to Freud, than horses when they "start moving" (Pferde sich in Bewegung setzen). ${ }^{10}$ Something else starts moving for Hans without his consciously willing anything about this: his penis, whose erections baffle him (2001, v. 10 , p. 135). The acceleration that begins when the horses start moving is the surge of life he feels in his involuntary erections, displaced onto a phobic signifier he articulates in the movement of his speech. More than a phenomenon of infantile sexuality, however, the great anxiety Hans articulates by means of his horse phobia is the corollary of knowing one exists, of the apperception of the movements of the unconscious that is the phenomenon of consciousness as Freud deduces it. That this phenomenon is manifest, as the case of Hans demonstrates, as Lacan argues in the wake of Freud's Project, only thanks to the movement of speech, means that anxiety is the price also of the unconscious' folding inside out, pulsating to eject the suffering ecstasy of the subject's scream, language made plastic as it is brought to the second power and manifesting movement in the psychic apparatus at its most intense.

\footnotetext{
${ }^{9}$ Aristotle (1984, 8.9.256b). See also Müller-Sievers (2015, p. 212).

10 "Analysis of a Phobia in a Five-Year-Old Boy" (FREUD, 2001, v. 10, p. 46; 1999, Bd. 7, p. 280).
} 
What this also means is that the phenomenon of speech, vehicle of the talking cure, is never completely sedative, nor should it be, for anxiety, just like love, can function as a median accessing the subject's desire (LACAN, 2014, p. 174) and serves as a compass in the clinic. That one speaks and hears one's self speak, perhaps especially in the resonance chamber that is the analytic cabinet, renders the realm of speech in its entirety what psychoanalyst Michèle Montrelay (1977, p. 123) calls a "phobic space," one in which "one circulates without great difficulty, except that all of a sudden the ground drops from under one's feet". At the moment of full speech such as the analyst listens for, when buccal orifice and the orifice that is the unconscious open to eject a fragment whose foundation is a scream that gives shape to the unpleasure of protoplasmic irritation, "psyche is extended," as Freud (2001, v. 23, p. 300) writes in one of his last notes. The psychic apparatus folds inside out, projecting itself as space whose center is a rotating vortex, a hole in motion generating anxiety. Lacan gives this hole the logical consistency of what he calls the object a. The chains of unconscious signifiers tangled around this object-hole, manifest in Hans's phobia in imaginary form as the "holes" and "behind-holes" ("Loch," "Podlloch") of the horses' sheds (2001, v. 10, p. 96; 1999, Bd. 7 , S. 331) are spatialized as intersecting routes in which circulation is possible "on condition the hole remains" (MONTRELAY, 1977, p. 132), swirling vortex in which one knows one is always already about to be lost.

In the face of größere Angst attendant upon being seized in the movement of speech without the privilege of knowing nothing about this, what subjective recourse? Hans is calmer when the cart the horses draw "stands still" (steht); also if he stops (Bleibt) in the street (2001, v. 10, p. $47 ; 1999$, Bd. 7, S. 281). In the face of the gaping hole at the center of phobic space, Montrelay (1977, p. 123) writes, "all one can do is freeze, no longer move". Phobic symptoms, then, are nothing but attempts to bring to a halt the acceleration of jouissance whose vector is infinite and whose most intense manifestation, Lacan suggests, is the movement of speech. Conscious strategies will never appease anxiety, for in order for a subject to tolerate his existence which is caught up in movement, Lacan says, it is not enough that he "perceive the acceleration that carries and transports him". It is also necessary that there be an arrest (LACAN, 1998a, p. 363). The metapsychological name of this arrest, which the phobic symptom attempts to mimic at considerable cost to the subject, is the castration complex as partial "annihilation" of jouissance (LACAN, 1998a, p. 363), more specifically, the little boy's subjective consent to register the functioning of the penis of the father with respect to the mother. The structural manifestation of the registration of castration, Lacan (1998a, p. 349) teaches, is "the transformation which translates movement into substitution, the continuity of the real into the discontinuity of the symbolic". In terms of Aristotelian physics, the moment of transformation Lacan speaks of when jouissance is annihilated for the subject by the functioning of a penis that is not his would be the transition of rotational into rectilinear motion, made possible by a boundary which contains (ARISTOTLE, 1984, 4.212a). But it is Aristotle's works not on physics but on language that teach much more about the transformation of motion that can arrest jouissance and hence render existence more tolerable for the being that speaks as it moves and moves as it speaks. Specifically, it is Aristotle's treatment of the category of scheme that profiles a locus in language where the enjoyed corporeal movement involved in speech as precipitate of the subject's scream that ejects an unconscious signifier, fragment of the protoplasm irritated by represented memory, is transformed from potentially infinite acceleration into acceleration that is crafted and punctuated.

What in Aristotle's Physics is denominated rotational motion whose vector is infinite has an isomorph in the treatment and topology of the category of $\sigma \chi \tilde{\eta} \mu \alpha$ (skhêma, scheme) in his works on language. In the Poetics and Rhetoric, $\sigma \chi \tilde{\eta} \mu \alpha$ is a general term for the components of $\lambda \dot{\varepsilon} \xi 1 \zeta$ (lexis) or style (ARISTOTLE, 1909, 1456b; 1927 , 3.8.1). In the Sophistical Refutations it denominates sophisms in their entirety (ARISTOTLE, 1955, 177a 2021). In the Sophistical Refutations, however, $\sigma \chi \tilde{\eta} \mu \alpha$ also designates a particular subdivision of sophisms, those ba-

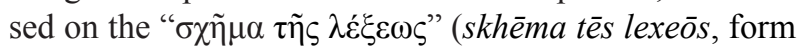
of expression) (ARISTOTLE, 1955, 166b10). Appearing on two levels of elocutionary taxonomy, the treatment of scheme in the Sophistical Refutations is thus a Moebian instance where these two levels become a continuous surface, where Aristotle's linguistic theory faces its own mise en abŷme, its own hole.

The Moebian structure of Aristotle's treatment of scheme in the Sophistical Refutations is precisely part of what makes it, for him, a point of unpleasure in the theory of language. Designating at once an elocutionary category and its subdivision, Aristotle's scheme is at odds with what to him is the principle of principles: there being one and only one word, with only one sense for a given thing. For a word not to have one sense, Aristotle $(1933,4.4 .1006 a-1006 b)$ states in the Metaphysics, is

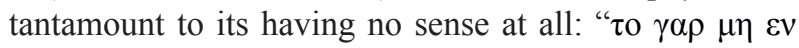

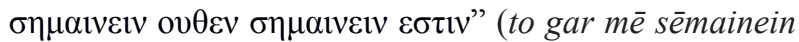
outhen sēmainein estin). The multiplication of sense, the polysemic potential of language that the unconscious exploits and that is retraced in the analyses of neurotics is thus, for Aristotle (1933, 4.4.1006b.10), not a resource of the cure it would be for Freud and Lacan, but "ovк

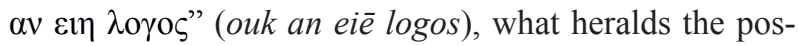
sible destruction of $\lambda$ oyo $\varsigma$ itself. ${ }^{11}$ Scheme as positioned in Aristotle's Rhetoric creates a hole in the univocity of sense, effects what Lacan (1976-1977, p. 124) in Seminar 24, and speaking of poetry, calls "hole effect" (effet de trou), opens up within semanticity an abyss where different senses swirl, undercutting diachrony to the benefit not of the stasis of synchrony but of vorticiality, the infinite motion that Aristotle in the Physics calls rotational. In Aristotle's theory of language, such vorticial polysemic motion at odds with the principle of non-contra-

${ }^{11}$ See Cassin (2013, p. 117-121). 


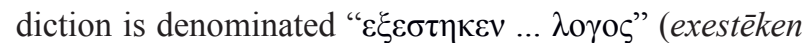
logos) (ARISTOTLE, 1927, 3.2.3), speech which ex-sists, subsists in the ex-static locus where Lacan (1998b, p. 22) in Encore situates the a certain real of jouissance. Permissible in poetry, it is marked out for expulsion from apodeictics, from logical and philosophical litigation with whose demonstrative thrust it is seldom " $\alpha \rho \mu$ ó $\tau \tau \varepsilon$ " (harmottei, harmonic).

The truth of what is at stake in this expulsion emerges not in the Rhetoric or the Poetics but in the Sophistical Refutations, where the exemplifications of $\sigma \chi \tilde{\eta} \mu \alpha$ at the Moebian point where it is a category at once general and particular include the articulation of "ótov $\tau$ o $\alpha \rho \rho \varepsilon v$

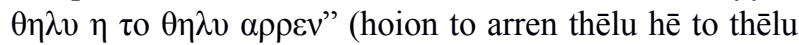
arren, masculine by feminine or feminine by masculine) (ARISTOTLE, 1955, 169a30). Beyond its Moebian topology, skhēma in the Sophistical Refutations thus shores up what is at stake, for Aristotle, in the troumatism or horror of the trou in sense, the $\{$ rik קיר (Hebrew, void) of rhet-o-ric qua re-turn to and around the void in language that opens up when a word is unmoored from a single sense: the erasure of a foundational difference which makes signification possible in the first place, the difference between masculine and feminine, sexual difference.

That for Aristotle the ultimate danger in the field of language is the danger of sexual equality is evinced also in the fourth rule for speech he lays down in the Rhetoric: to keep the " $\alpha \rho \rho \varepsilon v \alpha \kappa \alpha \operatorname{\theta } \theta \eta \lambda \varepsilon \alpha$ " (arrena kai thèlea, masculine and feminine) in words $\delta i \eta \rho \varepsilon \imath$ (diērei, distinct) (ARISTOTLE, 1927, 3.5.5). In Lacanian terms, this is the danger of the scotomization of the signifier functioning as the watershed of the formulae of sexuation - the phallic signifier, signifier of castration. This is the point of transsexual jouissance and the push to the woman Lacan $(2007 b$, p. 474) speaks of in relation to the clinic of the psychoses. It is also, differently, the point of the feminine jouissance that "with respect to everything that can be used in the function $\phi x$ [the phallic function], is in the realm of the infinite" (Encore, p. 103).

One of the manifestations of feminine jouissance as infinite as Lacan (1998b, p. 79) theorizes it in Encore is the "pleasure of speaking," using language as pure jou-

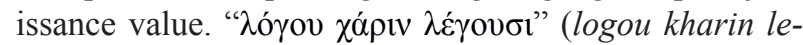
gousi) speaking in order to speak rather than in order to apodictically convey sense is Aristotle's description of this phenomenon, (ARISTOTLE, 1933, 4.5.1009a.2021). He finds it in the skhêmata of the sophists - anadiploses, epanalepses, apostrophes, parisons, antitheses, isocolons, alliterations - favouring the free play of signifiers capitalizing on the equivocation effected by sound, accent, prosody and ambiguous grammaticality over the univocity of signification upholding the principle of non-contradiction (CASSIN, 2013, p. 127). These are forms that make sense vacillate, either because of ambiguity of grammatical construction or because what is at stake in them is no longer grammar but the foundational unit of

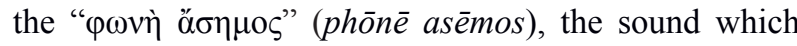
does not in itself mean (ARISTOTLE, 1995, 1456b). Destabilizing sense at the expense of the principle of non- -contradiction, schemata as Aristotle $(1995,1458 \mathrm{a})$ theorizes them make language " $\xi \varepsilon v ı$ òv" (xenikon), Other to itself. This xenification which aligns the skhemata with the radical alterity with which a jouissance without limits confronts the subject is precisely what justifies the necessity, for Aristotle, of admitting them into his logical-philosophical edifice only in stealth and on condition of an operation of subtraction (SHARON-ZISSER, 2016).

For Aristotle (1995, 3.1.5), then, the skhēmata of rhetoric are a perilous " $\pi \varepsilon \rho i ́ \varepsilon \rho \gamma \alpha$ " (perierga) (what is $\pi \varepsilon \rho i$, in the direction of, but still auxiliary to the univocally sense-making $\varepsilon \rho \gamma \alpha$ or work of language). In the Poet$i c s$, the excessive use of elocutionary schemes that do not mean is likened to an artistic act lacking the virtue

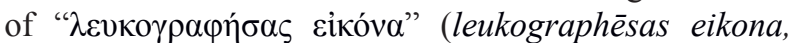
drawings of black on white) (ARISTOTLE, 1995, 1450b). The leukographic operation of the drawing of outlines indeed plays a structuring role in Aristotle's enterprise. Synecdochized in Aristotle's recommendation to adhere to a " $\pi \alpha \rho \alpha \tau \varepsilon i ́ v o " ~(p a r a t e i n o$, outline) of plot in drama $(1995,1451 b)$, it features in the programmatic statement

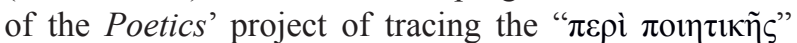
(peri poietikēs, circumference of the poetic) (1995, $1447 \mathrm{a}$ ), itself exemplifying the nomothetic thrust of the Aristotelian project in its entirety.

Interfering with the leukographics of Aristotle's nomothetic project, the use of sophistical schemes in apodeictics and even the excessive use of schemes in poetry is nevertheless said to endow speech with a " $\lambda \alpha \mu \pi \rho \alpha$ " (lampra, brilliance) $(1995,1460 \mathrm{~b})$ and to render it " $\theta \alpha v \mu \alpha \sigma \tau o ́ v "$ (thaumaston, effecting wonder) (1927, 3.2.3): seductive by virtue of its very insertion of a radi-

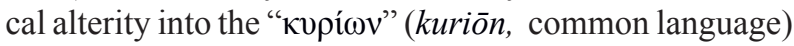
$(1995,1458 \mathrm{a})$. It is likened to the covering of a surface

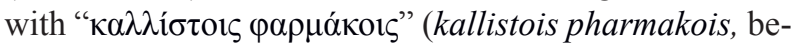
autiful colors) (ARISTOTLE, 1995, 1450b). Scheme in Aristotle's works on language thus partakes of the paradoxical logic of the pharmakos/pharmakon, the remedy-poison-color-scapegoat whose polyvalent vicissitudes in the Platonic text of the Phaedrus have been famously traced by Derrida (1981). A perilous element marked out for expulsion (the Platonic pharmakon) on account of its destabilizing the univocity of signification, it is at the same time designated a color (pharmakos) whose effects of beauty are recognized as responsible for the aesthetic pleasure proffered by the poetic text.

What renders the category of scheme, whose constitutive semantic polyvalence and Moebian positioning in the Aristotelian text make it, for Aristotle, a juncture of a jouissance supplementary to sense vorticially swirling in the hole it opens up in the univocity of language Aristotle holds dear nevertheless worthy of aesthetic praise? Several references to scheme in Aritotle's works on language suggest an answer, and this answer has to do with the metapsychology of motion with respect to language. Not least of these references is the inaugural treatment of scheme in what was to become Aristotle's most canonized work in aesthetic theory, the Poetics. Aristotle locates the elocutionary as part of a broad diapason of the arts which inclu- 
des the playing of musical instruments, visual art, whose medium is the chromatic, and the art of the "ó $\rho \chi \eta \sigma \tau \tilde{\omega} v "$ (orkheston, dancers), whose medium, Aristotle (1995, 1447a) says, is " $\sigma \chi \eta \mu \alpha \tau ו \zeta o \mu \varepsilon ́ v \omega v ~ \rho v \theta \mu \tilde{\omega} v "$ (skhēmatizomenōn rhuthmōn, rhythmic gestures). For Aristotle, then, the schematic is not only the elocutionary at the point at which it becomes vorticial, point of an infinite swirling of sense, but also the choreographic. It is motion which, diverging from the algorithms of specific action to the profit of aesthetic pleasure, follows the logic of erogenization as Freud unfolds it in the Three Essays on the Theory of Sexuality, ${ }^{12}$ on condition that it be part of a composition, that is, that it be not only erogenized but contrived.

Not limited to Aristotle's unfolding of the panoply of arts in the Poetics, the choreographic erogenization of scheme implicitly reappears in the opening sentence of the Rhetoric. "Rhetoric," Aristotle (1927, 1.1.1) writes

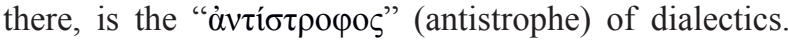
Inaugurating the theorization of rhetoric with a term denoting the ode lines chanted by the chorus in the theatre as it moves across the stage in response to the $\sigma \tau \rho о \varphi о \varsigma$, lines chanted in the opening move, Aristotle intricates rhetoric it from the outset with a motor action that is not specific but contrived. As a component of rhetoric, scheme in its elocutionary inflection partakes of this intrication, is hence at once elocutionary form and gesture. This intrication reverberates in the rhetorical tradition. Scheme, writes Richard Sherry (1961, p. 21), author of the first English rhetorical treatise in the vernacular, Treatise of Schemes and Tropes of 1550, "is a Greek word which signifies properly the gestures that dancers use to make".

What reveals the truth of this intrication, of the function of the schematic as crafted speech that is also crafted motion, is Aristotle's treatment of a rhetorical category on whose unprecedented elaboration he prides himself:

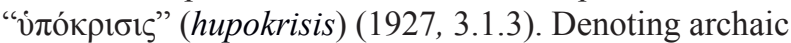
poets' practice of enacting the text of the tragedies they

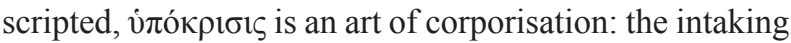
of a chain of signifiers and its metabolization into speech and movement. "Delivery" is the name later rhetorical treatises would give this practice, dividing it into "pronunciation" and "gesture," in Freudian terms, speech and symptomatic motor action as two forms in which the irritated protoplasm at the foundation of the unconscious signifier might emerge at moments of syncopation in which the unconscious opens up. In his sixth seminar, while discussing a text whose corporisation was to become the apex of an English acting career, Shakespeare's Hamlet, Lacan (1958-1959, p. 239) points out that such corporisation in effect takes place in the life of any neurotic subject with respect to the scripted scenarios of the unconscious phantasm, which the subject enacts with his organs: "the actor lends his members, his presence, not simply as a puppet, but with his unconscious which is well and truly real, namely the relationship of

\footnotetext{
${ }^{2}$ Freud writes: "To begin with, sexual activity attaches itself to one of the functions serving the purpose of self-preservation and does not become independent of them until later." That is, erogenization is mothing but the annexation of an anatomic function to the profit of pleasure. "Three Essays on the Theory of Sexuality" (FREUD, 2001, v. 7, p. 222).
}

his members to a certain history which is his own." In psychoanalytic terms, phantasmatic jouissance such saturates the speech of the neurotic subject and, at a lesser intensity, determines the symptomatic motions of his limbs.

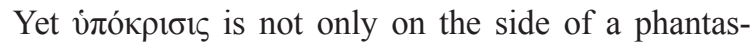
matic jouissance imbuing speech and symptom. Etymologically indicating what is beneath (vं ó$^{-}$), operates as a preliminary condition for, the act of judgment or dis-

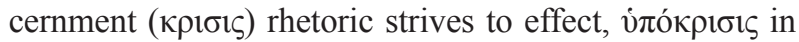
ancient Greek carries a diversified genealogy, from "to separate" to "to answer" to "to answer a fellow actor on stage" to "to play a part" (LIDDELL; SCOTT; JONES, 1901), a genealogy in which corporization does not exclude separation. In the ancient Greek theatre, the separation preliminary to the corporization of a dramatic text, the separation between an actor and the part he plays, involves an instrument that elides as it makes distinct: the mask, which in the Rhetoric is alluded to as, once again, $\sigma \chi \tilde{\eta} \mu \alpha$. Rhetoric, Aristotle writes in the first book of the Rhetoric,

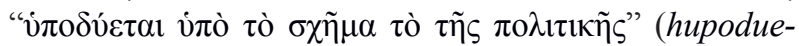
tai hupo to skhēma to tēs politikēs) (ARISTOTLE, 1927,

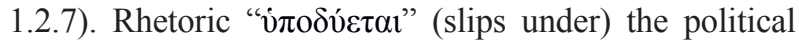
from which it derives so that the political becomes its $\sigma \chi \tilde{\eta} \mu \alpha$ : the form by means of which it appears but from which it remains dissonant and by which it is hidden.

$\sigma \chi \tilde{\eta} \mu \alpha$ as mask is, in the Rhetoric, the instrument for ن் in the Poetics, however, suggests that for Aristotle, this corporization is not limited to the use of the invocatory object (the voice) and the organs of the body, both susceptible, as Freud and Lacan teach, of being caught up in an acceleration that is nothing but the derivative of the movement of irritated protoplasm seeking its own extinction. In the Poetics, what is said to be "نं (hupokritikēs, an attribute of the art of vं person skilled in this art) is the " $\sigma \chi \eta \dot{\mu} \mu \alpha \tau \alpha \tau \tilde{\eta} \varsigma \lambda \varepsilon_{\varepsilon} \xi \varepsilon \omega \varsigma$ "

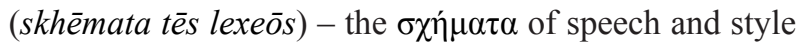
(ARISTOTLE, 1995, 1456b). $\sigma \chi \eta \dot{\mu} \alpha \tau \alpha$ as instruments of vं arena but the forms of elocution.

Rhetorical art as $\dot{\pi}$ óкрıбı, then, involves a process of corporization wherein signifierness affects zooic matter, and its instrument is the $\sigma \chi \eta \dot{\eta} \mu \alpha$. $\sigma \chi \eta \dot{\eta} \mu \alpha$ is thus the Aristotelian name for what makes separation within the process of corporisation possible, what guarantees that the signifierness that affects zooic matter stop short of the madness of total identification. $\sigma \chi \eta \mu \alpha$ is thus of the order of the limit to the illimited jouissance language can effect on zooic matter, whose analogue in Aristotelian physics is the infinity of rotational motion Lacan translates as acceleration, the limit Lacan teaches is phallic. $\sigma \chi \eta \dot{\mu} \mu \alpha$ in Aristotle's work on language is a site of phallic limitation no less than of a jouissance beyond the phallus, of arrest no less than of acceleration. While its tendency to make sense vacillate generates vorticial holes in the univocal fabric of language Aristotle is keen to maintain, it at the same time arrests the potentially infinite movement of polysemia within these vorticial holes by virtue of the 
very fact of its being contrived, stylized speech. $\sigma \chi \tilde{\eta} \mu \alpha$ as contrived speech, $\sigma \chi \tilde{\eta} \mu \alpha$ as stylized choreographic motion, $\sigma \chi \tilde{\eta} \mu \alpha$ as theatrical mask guaranteeing a minimal distance between actor and dramatic role - such are the points of arrest that Aristotle teaches us to recognize within his treatment of scheme, otherwise aligning category with vorticial motion not only because of the semantic polyvalence it can generate but because of its Moebian structure which causes the hypotaxis of Aristotle's theory of language to fold in on itself.

The function of scheme in Aristotle's work on language to arrest the potentially infinite acceleration of speech and movement in which the subject is caught not only explains Aristotle's granting it an agalmatic status. It teaches the analyst that these elocutionary schemes, "at work in the rhetoric of the discourse the analysand actually utters" are significant not only because, as Lacan (2007c, p. 433) affirms in "The Instance of the Letter in the Unconscious", they are not the veil but the actual manifestation of unconscious mechanisms but also because they serve the subject as condensators of an excess jouissance that troubles his limbs.

The metapsychological lesson of Aristotle's treatment of scheme in his works on language is that beyond granting the subject's scream, invocatory manifestation of the movement of irritated protoplasm in plastic form that can be ejected from the unconscious in what Montrelay (1981) calls moments of the leap, speech includes, in the category of scheme, the means of arresting this movement, otherwise potentially non-signifying and infinite. If signifiers ejected from the unconscious in the course of the analysand's speech are charged with movement in the psychic apparatus at its most intense, scheme as theorized in Aristotle's works on language is at once situated as what manifests this potentially infinite movement and signalled as what might attenuate this movement, substitute the discontinuity not of the signifier but of stylized form for the continuity of the real as masses in motion. Operating as does a phobic symptom, scheme in its Aristotelian declension is a congealing that creates a rim in what would otherwise be a swirling vortex of enjoyment in language and/as body. It is where the staged movements of a choreography attain the status of a bien dire and where the bien dire of an analysand reveals itself as what moves to organ-ize a jouissance in excess. Perhaps especially at the ultima thule of analysis: the unprecedented choreography of an exit.

\section{References}

ARISTOTLE. On the Art of Poetry. Trans. I. Bywater. Oxford: Oxford Clarendon Press, 1909.

ARISTOTLE. The Art of Rhetoric. Trans. J. H. Freese. Cambridge, MA: Harvard University Press, 1927.

ARISTOTLE. Metaphysics. Trans. Hugh Tredennick. Cambridge, MA: Harvard University Press, 1933.

ARISTOTLE. On Sophistical Refutations. Trans. E. S. Forster and D. J. Furley. Cambridge, MA: Harvard University Press, 1955.
ARISTOTLE. Physics. Trans. R. P. Hardie and R. K. Gaye. In: BARNES, J. (Ed.). The Complete Works of Aristotle. Princeton, NJ: Princeton University Press, 1984. p. 315-446.

ARISTOTLE. Poetics. Trans. W. Hamilton Fyfe and Doreen C. Innes. Cambridge, MA: Harvard University Press, 1995.

CASSIN, B. Jacques le Sophiste: logos et psychanalyse. Paris: EPEL, 2013.

CICERO, M. T. On the Orator. Trans. E. W. Sutton and H. Rackham. Cambridge, MA: Harvard University Press, 1948.

DERRIDA, J. Plato's Pharmacy. In: Dissemination. Trans. Barbara Johnson. Chicago: The University of Chigaco Press, 1981. p. 63-171.

FREUD, S. Aus den Anfängen der Psychoanalyse: Briefe an Wilhelm Fliess, Briefe 52. Frankfurt, S. Fischer, 1962.

FREUD, S. Gesammelte Werke. FREUD, A. (Ed.). Frankfurt: S. Fischer, 1999. 18 Bde.

FREUD, S. The Standard Edition of the Complete Psychological Works of Sigmund Freud. STRACHEY, J. et al. (Trans.). London: Vintage, 2001. $24 \mathrm{v}$.

LACAN, J. The Seminar of Jacques Lacan: Desire and its Interpretation (1958-1959). Trans. Cormac Gallagher. Book 6. Available at: <http://www.lacaninireland.com/web/wp-content/ uploads/2010/06/Book-06-Desire-and-its-interpretation.pdf>. Access in: 17 Dec. 2016.

LACAN, J. The Seminar of Jacques Lacan: l'insu que sait de l'une-bévue s'aile à mourre (1976-1977). Trans. Cormac Gallagher. Book 24. Available at: <http://www.lacaninireland. com/web/wp-content/uploads/2010/06/insu-Seminar-XXIVFinal-Sessions-1-12-1976-1977.pdf>. Access in: 12 Dec. 2016.

LACAN, J. The Seminar of Jacques Lacan: The Moment to Conclude (1977-1978). Trans. Cormac Gallagher. Book 25. Available at: <http://www.lacaninireland.com/web/wp-content/ uploads/2014/03/Book-25-The-Moment-to-Conclude.pdf $>$. Access in: 18 Dec. 2016.

LACAN, J. The Seminar of Jacques Lacan: The Four Fundamental Concepts of Psychoanalysis (1964). Ed. JacquesAlain Miller, trans. Alan Sheridan. New York: [s.n.], 1978. Book 11.

LACAN, J. The Seminar of Jacques Lacan: The Psychoses 1955-1956. Ed. Jacques-Alain Miller, trans. Russell Grigg. New York: [s.n.], 1993. Book 3.

LACAN, J. Le séminaire de Jacques Lacan: la relation d'objet. Ed. Jacques-Alain Miller. Paris: [s.n.], 1998a. Livre 4.

LACAN, J. The Seminar of Jacques Lacan: Encore. Ed. Jacques-Alain Miller, trans. Bruce Fink. New York: Norton, 1998b. Book 20.

LACAN, J. The Seminar of Jacques Lacan: The Ethics of Psychoanalysis 1959-1960. Ed. Jacques-Alain Miller, trans. Dennis Porter. New York: Routledge, 1999. Book 7.

LACAN, J. The Function and Field of Speech and Language in Psychoanalysis. Trans. Bruce Fink. In: Écrits. New York: W. W. Norton \& Company, 2007a. p. 197-268.

LACAN, J. On a Question Preliminary to Any Possible Treatment of Psychosis. Trans. Bruce Fink. In: Écrits. New York: W. W. Norton \& Company, 2007b. p. 445-488. 
LACAN, J. The Instance of the Letter in the Unconscious. Trans. Bruce Fink. In: Écrits. New York: W. W. Norton \& Company, 2007c. p. 412-444.

LACAN, J. The Seminar of Jacques Lacan: Anxiety (19621963). Ed. Jacques-Alain Miller, trans. Adrian Price. New York: [s.n.], 2014. Book 10.

LEWIS, C. T.; SHORT, C. A Latin Dictionary. Perseus Digital Library. Available at: <http://www.perseus.tufts.edu/hopper/ text?doc=Perseus:text:1999.04.0059>. Access in: 20 Dec. 2016.

LIDDELL, H. G.; SCOTT, R.; JONES, H. S. A Greek-English Lexicon. Oxford: Oxford University Press, 1901.

MILLER, J.-A. Biologie lacanienne et évènement de corps. La Cause freudienne, Paris, v. 44, p. 5-45, févr. 2000.

MONTRELAY, M. L'Ombre et le nom: sur la féminité. Paris: Minuit, 1977.

MONTRELAY, M. Aux frontiers de l'inconscient freudien. Confrontation, n. 6, p. 23-32, 1981.

MÜLLER-SIEVERS, H. The Science of Literature: Essays on an Incalculable Difference. Berlin: De Gruyter, 2015.

SHARON-ZISSER, S. Calliope's Sc(D)ream: Feminine Jouissance in Aristotle's Works on Language. The Letter: Irish Journal of Lacanian Psychoanalysis, n. 62, p. 37-64, Nov. 2016. Available at: <http://theletter.ie/shirley-sharon-zissercalliopes-scdream-feminine-jouissance-in-aristotles-works-onlanguage/>. Access in: 18 Dec. 2016.

SHERRY, A. Treatise of Schemes and Tropes. Ed. H.W. Hildebrandt. Gainesville, Fl.: Scholars' Facsimiles \& Reprints, 1961.

Received on: January 27, 2017

Accepted: February 07, 2017 